\title{
Acute Dystonia Caused by Clomipramine: a Case Report
}

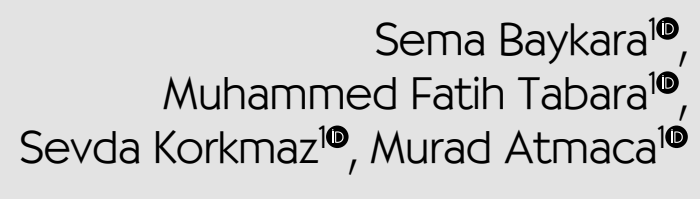

${ }^{\prime}$ Firat University, Faculty of Medicine, Department of Psychiatry, Elazig - Turkey

\section{ABSTRACT}

Acute dystonia caused by clomipramine: a case report

Drug-induced acute dystonia is a movement disorder that occurs most often with neuroleptics, though there are many drugs in its etiology. The exact mechanism of antidepressant-associated extrapyramidal side effects (EPS) is not known. However, hypotheses including inhibition of dopaminergic function in the nigrostriatal pathway, impaired balance between dopaminergic, serotonergic, noradrenergic or cholinergic activity, and serotonergic inhibition of dopaminergic functions in the striatum leading to extrapyramidal side effects have been suggested. The number of cases with acute dystonia during clomipramine use is low. We wish to draw attention to this rare side effect of clomipramine and to contribute to the literature by presenting a case of acute dystonia on the $5^{\text {th }}$ day of clomipramine treatment in a 19-year-old male patient.

Keywords: Antidepressants, clomipramine, dystonia

\section{öz}

Klomipraminin neden olduğu akut distoni: Bir olgu sunumu

Illaç kullanımıyla ortaya çıkan akut distoni, etiyolojisinde birçok ilacın olduğu ama en sık nöroleptiklerle ortaya çıkan bir hareket bozukluğudur. Antidepresan kullanımı ile ortaya çıkan ekstrapiramidal yan etkilerin oluş mekanizması tam olarak bilinmemektedir. Ancak, dopaminerjik fonksiyonların nigrostriatal yolakta inhibe edilmesi, dopaminerjik, serotonerjik, noradrenerjik veya kolinerjik aktivite arasındaki dengenin bozulması, striatumda dopaminerjik fonksiyonların serotonin tarafından inhibisyonunun ekstrapiramidal yan etkilere yol açması ileri sürülen hipotezlerdendir. Literatürde klomipramin kullanımı sonrasında akut distoni gelişen vaka sayısı nadirdir. Biz 19 yaşındaki erkek hastamızda klomipramin kullanımının 5. gününde ortaya çıkan akut distoni gelişimi olgusunu sunarak klomipraminin nadir görülen bu yan etkisine dikkat çekmek ve literatüre katkıda bulunmak istedik.

Anahtar kelimeler: Antidepresan, klomipramin, distoni

How to cite this article: Baykara S, Tabara MF, Korkmaz S, Atmaca M. Acute dystonia caused by clomipramine: a case report. Dusunen Adam The Journal of Psychiatry and Neurological Sciences 2018:31:396-399.

https://doi.org/10.5350/DAJPN2018310408

\author{
Address reprint requests to / Yazışma adresi: \\ Sema Baykara, \\ Firat University, Faculty of Medicine, \\ Department of Psychiatry, 23119 Elazig, Turkey \\ Phone / Telefon: +90-424-233-3555/2970 \\ E-mail address / Elektronik posta adresi: \\ semabaykara@hotmail.com \\ Date of receipt / Geliş tarihi: \\ March 9, 2017 / 9 Mart 2017 \\ Date of the first revision letter / \\ ilk düzeltme öneri tarihi: \\ April 2, 2017 / 2 Nisan 2017 \\ Date of acceptance / Kabul tarihi: \\ April 18, 2018 / 16 Nisan 2018
}

\section{INTRODUCTION}

$\mathrm{D}$ ystonia is defined as an acute tonic muscle spasm, often affecting tongue, jaw, eyes, and neck, sometimes seizing the entire body. It sets on suddenly and is uncomfortably painful for the patient. The condition is more frequently seen in young persons. The spasms in the neck can present as opisthotonus or torticollis. Spasms in the ocular muscles can turn the eyes sidewise or upwards (oculogyric crisis). The tongue may be enlarged and extend outwards in a laryngospasm or jaw dystonia (1). While the physiopathological mechanisms have not yet been fully explained, it is assumed that an imbalance between the striatal dopaminergic and cholinergic systems due to a sudden and extreme blockage of the dopamine receptor is responsible for this presentation. Drug-induced dystonia mostly originates from substances blocking dopamine activation, especially those blocking dopamine D2 receptors in the caudate, putamen, and globus pallidus (2,3). Other drugs causing dystonia are those changing the balance between serotonin and dopamine or dopamine and acetylcholine in the basal ganglia (4-6). Clomipramine is a tertiary amine tricyclic antidepressant with specific D2 antagonist activity and strong serotonin reuptake inhibitor properties. The most important side effects reported are vertigo, hypokinesia, headache, 
irritability, constipation, increased appetite, nausea, dryness of the mouth, increased perspiration, and cardiac side effects. Other potential side effects are convulsions and an increased disposition for convulsions (7). By contrast, our paper presents a patient developing dystonia with clomipramine.

\section{CASE}

A 19-year-old single male university student had seven months previously began developing complaints of shortness of breath, a sensation of chest pressure, palpitation, and pain in back and arms. With these complaints, he presented at the policlinics for pulmonary medicine and cardiology. The complaints recurred in paroxysmal form once every 15-20 days. Around 4 months previously, fainting and paresthesia in the limbs developed in addition to the earlier complaints. The patient presented at the neurology policlinic; however, no neurological findings were determined. As the complaints did not recede, one month previously the patient attended the psychiatric policlinic, receiving a diagnosis of anxiety disorder and conversion disorder. He was prescribed sertraline $50 \mathrm{mg}$ and alprazolam $0.5 \mathrm{mg}$. As the complaints did not resolve within one month, the patient was admitted to the psychiatry ward with complaints of distress, palpitation, breathing difficulties, syncope, and paresthesia in hands and feet. He was diagnosed with conversion disorder and anxiety disorder according to DSM-5 (8). The patient was started on clomipramine $50 \mathrm{mg} /$ day and alprazolam $1 \mathrm{mg}$ /day. On the $3^{\text {rd }}$ day of hospitalization, the clomipramine dose was increased to $75 \mathrm{mg} /$ day. However, on the $5^{\text {th }}$ day of hospitalization, spasms in the neck and inward contractions and flexions in arms and legs set in. Hemogram and blood biochemistry ( $\mathrm{Na}, \mathrm{K}, \mathrm{Ca}, \mathrm{Mg}$, urea, creatinine, etc.) had been normal during hospitalization. An emergency reassessment did not result in any pathological findings. A neurological consultation was requested to investigate the potential presence of an organic disease. The results of the neurological examination did not suggest any organic etiology. Thus it was decided to reassess the patient with MR imaging, cerebral venography, and EEG under hypnosis. Considering that the patient might have developed an acute drug-related dystonia, clomipramine treatment was discontinued and biperiden $5 \mathrm{mg}$ IM was administered. Within one hour, a reduction in the patient's complaints of spasms was observed. The side effects were assessed according to Naranjo's Adverse Drug Reaction Probability Scale, which measures to what degree an adverse drug effect is likely to be drug-related rather than caused by other factors (9). Our patient scored a total of 8 points on the scale, which corresponds to a highly probable relation. The patient's treatment was set to tablet escitalopram $10 \mathrm{mg} /$ day, tablet biperiden $4 \mathrm{mg} /$ day, and tablet diazepam $10 \mathrm{mg} /$ day. Results of MR imaging, cerebral venography, and EEG under hypnosis as well as a neurological reassessment found no pathologies, which suggests that the spasms may have been drug-related. As the spastic complaints decreased, the biperiden dose was reduced to $2 \mathrm{mg}$ /day and the complaints resolved after one week of progressive reduction. Given that the general complaints also decreased quickly, it was planned to phase out biperiden. On the $12^{\text {th }}$ day of hospitalization, the patient was discharged with a medication plan of biperiden $2 \mathrm{mg}$ /day and diazepam $5 \mathrm{mg}$ /day. During the follow up examination it was seen that the patients had no contractions, and the treatment rearranged.

\section{DISCUSSION}

Acute dystonia can be caused by a number of triggers, the most commonly seen cause being a drugrelated side effect. In the literature, the following drug classes are reported as triggers for acute dystonia: neuroleptics, antiemetics, tricyclic antidepressants, monoamine oxidase inhibitors (MAO inhibitors), selective serotonin reuptake inhibitors (SSRIs), serotonin antagonist and reuptake inhibitors (SARIs), serotonin-noradrenaline reuptake inhibitors (SNRIs), antiepileptic drugs (phenytoin, carbamazepine, diazepam), and antimigraine drugs (sumatriptan) (4-6,10-13). For typical antipsychotics, a 2.3 to $60 \%$ risk to develop acute dystonia has been reported (14), 
while for atypical antipsychotics, a risk between 2 and $3 \%$ has been found (15). Antidepressants are also known to cause dystonia, though not at the level of antipsychotics. A case series reported that the SSRI group entailed a higher risk than other antidepressants $(3,16)$. It is known that an increased blood level of SSRIs like paroxetine and fluvoxamine can increase the risk of acute dystonia (17). Gill et al. (3) reviewed studies examining extrapyramidal side effects related to cyclic antidepressants, determining an occurrence of akathisia in $26 \%$ of tricyclic antidepressant (TCA) use cases, dystonia in $17 \%$ of cases, reversible dyskinesia in $52 \%$, and neuroleptic malignant syndrome in $4 \%$ of cases.

TCAs block serotonin and noradrenaline reuptake pumps and, to a lesser degree, dopamine reuptake pumps as well. Some TCAs (such as clomipramine) are more powerful inhibitors of serotonin reuptake pumps; others are more selective for noradrenaline than for serotonin (desipramine, maprotiline, nortriptyline, protriptyline). However, most TCAs block serotonin as well as noradrenaline reuptake (18). While older sources generally state that extrapyramidal side effects in TCA use are rarely seen, studies and case reports published in recent years suggest that extrapyramidal side effects in TCA use are frequent but often go undiagnosed because of insufficient recognition (5). The first case reports describing antidepressant-related extrapyramidal side effects appeared in the 1950s. In 1959, Foster and Lancaster (19) presented a number of cases describing coarse tremor as a result of imipramine use. In the mentioned review article on TCA-related extrapyramidal side effects, it was determined that these effects were not frequently seen and not related with age but rather dose-dependent (3). A study made in 2002 showed that extrapyramidal side effects with the use of TCAs were dose-dependent and resolved with a reduction of the drug dose or its discontinuation (5). These side effects were reported to be related with advanced age, female sex, cytochrome P2D6 (CYP2D6)-inhibiting drugs, and the presence of D2 receptor polymorphism (4). As far as we could see, there are only a small number of reports about incidents with clomipramine use in the literature, like one case with clomipramine (20) and one with a joint use of haloperidol and clomipramine (21).
Ninety percent of acute dystonias occur within the first 3 days after drug use (1). In our case, involuntary spasms and flexions in hands and feet and neck spasms began after a short time, around five days after starting clomipramine. When the treatment of acute dystonia is started early, response is usually quick $(12,22)$. Our patient was given $5 \mathrm{mg}$ biperiden IM. His complaints of spasms decreased within one hour. IM injection of anticholinergic drugs resolves symptoms within a few minutes, and repeat injections are usually not required. In oral treatment with anticholinergic drugs, it is important to continue for a period between 48 hours and 7 days to prevent recurrence of symptoms (22). In our case, after a single dose of $5 \mathrm{mg}$ biperiden IM and a subsequent therapy with $4 \mathrm{mg}$ /day biperiden orally the patient's complaints of spasms progressively decreased over the course of one week, and he was discharged with a reduced dose of biperiden ( $2 \mathrm{mg}$ ) with recommended follow-up examination one week later.

TCAs are a group of antidepressants frequently used in the treatment of a number of psychiatric diseases. By presenting a case with acute dystonia, a rarely seen side effect of these drugs, we want to draw the clinicians' attention to this TCA side effect and contribute to the literature.

\begin{tabular}{|l|l|l|}
\hline \multicolumn{2}{|l|}{ Contribution Categories } & Author Initials \\
\hline \multirow{4}{*}{ Category 1} & Concept/Design & S.B. \\
\cline { 2 - 3 } & Literature review & S.B., M.F.T. \\
\cline { 2 - 3 } & Data analysis/Interpretation & S.B., M.F.T. \\
\cline { 2 - 3 } & Case follow-up (if applicable) & S.K., M.A. \\
\hline \multirow{3}{*}{ Category 2} & Drafting manuscript & M.F.T., S.B. \\
\cline { 2 - 3 } & Critical revision of manuscript & S.K., M.A. \\
\hline Category 3 & Final approval and accountability & S.B., M.F.T., S.K., M.A. \\
\hline \multirow{3}{*}{ Other } & Technical or material support & N/A \\
\cline { 2 - 3 } & Supervision & N/A \\
\cline { 2 - 3 } & Securing funding (if applicable) & N/A \\
\hline
\end{tabular}

Informed Consent: Written consent was obtained from the participants.

Peer-review: Externally peer-reviewed.

Conflict of Interest: Authors declared no conflict of interest.

Financial Disclosure: Authors declared no financial support. 


\section{REFERENCES}

1. Ozturk MO. Mental Health and Mental Disorders. Ankara: Nobel Medicine Bookstores, 2015. (Turkish)

2. Domínguez-Morán JA, Callejo JM, Fernández-Ruiz LC, Martínez-Castrillo JC. Acute paroxysmal dystonia induced by fluoxetine. Mov Disord 2001; 16:767-769. [CrossRef]

3. Gill HS, DeVane CL, Risch SC. Extrapyramidal symptoms associated with cyclic antidepressant treatment: a review of the literature and consolidating hypotheses. J Clin Psychopharmacol 1997; 17:377-389. [CrossRef]

4. Madhusoodanan S, Alexeenko L, Sanders R, Brenner R. Extrapyramidal symptoms associated with antidepressants - a review of the literature and an analysis of spontaneous reports. Ann Clin Psychiatry 2010; 22:148-156.

5. Schillevoort I, van Puijenbroek EP, de Boer A, Roos RA, Jansen PA, Leufkens HG. Extrapyramidal syndromes associated with selective serotonin reuptake inhibitors: a case control study using spontaneous reports. Int Clin Psychopharmacol 2002; 17:75-79.

\section{[CrossRef]}

6. Najjar E, Price LH. Citalopram and dystonia. J Am Acad Child Adolesc Psychiatry 2004; 43:8-9. [CrossRef]

7. Baykara S, Korkmaz S, Taşcı G, Kaya S, Atmaca M. Edema induced with clomipramine. Journal of Mood Disorders (JMOOD) 2016; 6:238-241. [CrossRef] (Turkish)

8. American Psychiatric Association. Diagnostic and Statistical Manual of Mental Disorders (DSM-5®). Fifth ed., Washington DC: American Psychiatric Pub., 2013.

9. Naranjo CA, Busto U, Sellers EM, Sandor P, Ruiz I, Roberts EA, Janecek E, Domecq C, Greenblatt DJ. A method for estimating the probability of adverse drug reactions. Clin Pharmacol Ther 1981; 30:239-245. [CrossRef]

10. Hedenmalm K, Guzey C, Dahl ML, Yue OY, Spigset O. Risk factors for extrapyramidal symptoms during treatment with selective serotonin reuptake inhibitors, including cytochrome P-450 enzyme, and serotonin and dopamine transporter and receptor polymorphisms. J Clin Psychopharmacol 2006; 26:192197. [CrossRef]

11. Shin HW, Chung SJ. Drug induced parkinsonism. J Clin Neurol 2012; 8:15-21. [CrossRef]
12. Robottom BJ, Shulman LM, Weiner W.J. Drug-induced movement disorders: emergencies and management. Neurol Clin 2012; 30:309-320. [CrossRef]

13. Bondon-Guitton E, Perez-Lloret S, Bagheri H, Brefel C, Rascol $O$, Montastruc JL. Drug-induced parkinsonism: a review of 17 years' experience in a regional pharmacovigilance center in France. Mov Disord 2011; 26:2226-2231. [CrossRef]

14. Cunningham Owens DG. A Guide to the Extrapyramidal Side-Effects of Antipsychotic Drugs. Cambridge: Cambridge University Press, 1999. [CrossRef]

15. Pierre JM. Extrapyramidal symptoms with atypical antipsychotics: incidence, prevention and management. Drug Saf 2005; 28:191 208. [CrossRef]

16. Baykara, S. Oromandibular dystonia with sertraline treatment: a case report. Anatolian Journal of Psychiatry 2017; 18(Suppl.1):5961. [CrossRef]

17. Sproule BA, Naranjo CA, Bremmer KE, Hassan PC. Selective serotonin reuptake inhibitors and CNS drug interactions: a critical review of the evidence. Clin Pharmacokinet 1997; 33:454471. [CrossRef]

18. Stahl SM. Essential Psychopharmacology Neuroscientific Basis and Practical Applications Second Ed. Cambridge: Cambridge University Press; 2000.

19. Foster AR, Lancaster NP. Disturbance of motor function during treatment with imipramine. Br Med J 1959; 2:1452-1453. [CrossRef]

20. Chithiramohan RN, Ballard CG, Measey LG. Acute dystonia induced by clomipramine therapy. Ir J Psychol Med 1990; 7:141142. [CrossRef]

21. Starkey SR, Morrisey JK, Hickam HD, Albright JD, Lynch MJ. Extrapyramidal side effects in a blue and gold macaw (Ara ararauna) treated with haloperidol and clomipramine. J Avian Med Surg 2008; 22:234-239. [CrossRef]

22. van Harten PN, Hoek WH, Kahn RS. Acute dystonia induced by drug treatment. BMJ 1999; 319:623-626. [CrossRef] 